\title{
The First Rush of Movement: A Phenomenological Preface to Movement Education
}

\author{
Dr. Stephen J. Smith, Simon Fraser University, Canada \\ Email: stephen_smith@sfu.ca
}

\section{Abstract}

Children's lived experiences of movement indicate possibilities for teaching them to be at home in increasingly challenging domains of activity. Especially significant are movements that reflect landscape connection, that carry an intention not confined to individual purpose, and that are enhanced by observational glance. The first rush of movement is described phenomenologically as an essential feature of these movements and of the vital consciousness they engender. The phenomenon of the first rush of movement attests to a mimetic impulse towards otherness that overrides personal motive and moderates an otherwise containing gaze. Its intentionality is evident in an extended, inclusive and progressive range of human movements that affirm a natural, intimate relation with others and the world at large. The embrace, caress and kiss are described as primary, elemental gestures from which movement disciplines sustaining the first rush of moment and its mimetic impulse can be cultivated. Accordingly, this study prefaces a practice of education in which children's movements, originating in responsiveness to landscape and motivated by a mimetic impulse, can be guided towards enhanced and sustaining world relations. Vital qualities of movement can be sustained from childhood to adulthood and from the most rudimentary contacts with the world to the most refined, skill-based encounters.

\section{Introduction}

While movement educators, physical educators, body therapists, physiotherapists, and kinesiologists have long paid attention to physical growth and development, it is only recently that the body has been recognized non-mechanistically in wider educational circles as a sentient medium of learning. Witness, for instance, the emergence of Howard Gardner's (1983) notion of "bodily-kinesthetic intelligence," Kieran Egan's (1997) formulation of "somatic understanding" and Richard Shusterman's (1997) "somaesthetics." But this focus on the body, for all its merits, still fails to address the embodied consciousness of the child and the intercorporeal consciousness of adults interacting with children. It is an ontological fact that consciousness is embodied through and through. This is the message of the myriad phenomenologies of 
embodiment, whether feminist, poststructuralist or more classically phenomenological, that critique the abstractions of bodily detachment (e.g. Grosz, 1994; Olkowski \& Weiss, 2006; Welton, 1999). That children are embodied beings who experience the world sensually, kinaesthetically, and con-sensually (Sheets-Johnstone, 1999) is also the premise of the present study. Embodied consciousness is, demonstrably for children but no less so for adults, inherently relational. It is not in the first instance a matter of skills, techniques and patterns of motor behaviour, but rather of "corporeal schemata" (Merleau-Ponty, 1962). These arise naturally through bodily immersion in movement. They are shaped through motions elicited by the world and through the mimetic gestures of face-to-face bodily engagements of adults and children.

Children move naturally in the world and adults can remember what it is like to move as children do. Movement is, for children and adults, a primary consciousness. It is a fundamental animation of behaviour, feeling, and thought that discloses essential connectedness to one another and to the world in which we live. The following narrative illustrates this well. In its remembrance of a particular childhood experience, it evokes a child's sensibility and, in its nostalgic tone, it indicates a residue of movement consciousness that might become more sustained. Here the Canadian novelist Margaret Atwood (1972) recalls a time of childhood when motions such as swimming and diving in a lake were the primary means of connecting to the world.

I go off the dock and wade in from the shore, slowly, splashing water over my shoulders and neck, the cold climbing my thighs; my footsoles feel the sand and the twigs and sunk leaves. At [one] time I would dive and coast along the lake floor with my eyes open, distance and my own body blurred and eroding; or out further, diving from the canoe or the raft and turning on my back under the water to look up, the bubbles fleeing from my mouth. We could stay in until our skins became numbed and turned a strange color, bluish-purple. I must have been superhuman, I couldn't do it now. Perhaps I'm growing old, at last, can that be possible? (p. 74)

Margaret Atwood's words position a phenomenological study of the movements of children. She remembers a physicality of childhood that is located, not in the realm of an 'I can't,' but of an 'I can. ${ }^{1}$ She remembers her movements as being sensorially connected and responsive to the water, and as blurring any bodily distance from the liquid features of the lake. She remembers the delight of her motions in the water, and none of the cold that would otherwise dull that emotion. ${ }^{2}$ In this remembrance, Atwood identifies a time and space of movement and a sense of waterscape connection that seemingly separates the child's "superhuman" powers from her own aging, adult containment. But the question arises: What is the materiality, corporeality or, in effect, the physical reality to this separation of adult and child? If such a separation exists, what then are we to make of the appeal of the remembrance itself? What are we to make of other adults "bracing to take the plunge" (c.f. MacGregor, 2002, p. 36) and, indeed, of those seemingly "superhuman" adult powers of movement that, diving underwater, also "become fluid as water, in water" (c.f. Ecott, 2001, p. 326)? 
Further examples are needed to explore the continuity of children's movement experiences. We shall refer to these in due course. Let us first look at the motility field of childhood with the phenomenological resources that are at hand. Referring to a few classic phenomenological studies, held up to the light of recent developments in eco-pedagogy and ecophenomenology, the present study can thus be regarded as an exploration of the enduring "significance of human movement" (Van den Berg, 1952). It is undertaken in light of "the child's relations with others" (Merleau-Ponty, 1964a), and also with a landscape of otherness. Together, these relationships elicit movement, connect the child's movements to our own, and ultimately serve as the originating source of meaning for movement. Following F.J.J. Buytendijk (1958): "Our task is to deepen our understanding of this point. It demands the joining of philosophic anthropology, methodological reflection and all our concrete experience of human relations" (p. 112). Consequently we shall extend the analysis of the significance of human movement by investigating the quite remarkable phenomenon of the first rush of movement. Merleau-Ponty's insights will help us establish this phenomenon as pivotal in understanding the developmental significance of children's movement. We shall then describe this experience in rich, narrative detail, thereby aiming to open up a field of elemental gestures, primary motions, and movement disciplines that define a fundamental domain of educative practice.

\section{The significance of children's movements}

J.H. Van den Berg (1952) locates "the significance of human movement" in three places: first of all, in the landscape of action; second, in the intention of the moving person; and third, in the "glance of another" who sees a person's motion and lends it human consciousness (p. 127). Van den Berg follows Husserl's and Heidegger's redefinition of intentionality as a consciousness of the world in which the things of the world have a primary spatiality and temporality. He claims that we show ourselves in our different modes of presence amongst the things of the world and that these things have "landscape value" as determinative of who we are from place to place and time to time. Human movement does not so much emanate from a subject as it locates the subject within a landscape that appeals to his or her movements and so situates their meaning. Accordingly, the meanings of psychology (as the discipline that defines the individual meaning of human movement) and of phenomenology (with its interest in the derivation of movement from landscape; e.g. Abram, 1996; Brown and Toadvine, 2003; Mazis, 2002) are redefined. Each can be said to be "in the first place [to be] metereology, physiology of the elements: earth, air, water, and fire....Psychology is cosmology" (Van den Berg, p. 102, original emphasis).

Let us see what such a phenomenology of human movement discloses of the consciousness of movement and of the "landscape value" of the motions of children. Put another way, if children exist "in movement" even more obviously than adults, and if we are to understand what this means for our relations with children, then we must come to terms with how children and their landscapes of action are "held together only in movement" and what this connection says of a natural "topology of being" (Merleau-Ponty, 1964b, pp. 21-22). 


\section{The first rush of movement}

It is within the landscape of action that a distinctive phenomenon is located, namely, that first rush of movement that is discernible as childhood vitality, playfulness, exuberance, spontaneity, and delight. It is the effervescent, transporting motion of being captivated by the landscape where one is no longer able to contain oneself. This first rush of movement appears preconsciously, prior to the sense I might subsequently have of my physical status as the instigator and coordinator of my movements. I identify with the world as a gestured presence, a point or concentration of movement, "a node in a vast field of energies and meanings" (Mazis, 2002, p. 1). The first rush of movement appears to be neither of my own volition nor a bodily imperative acting upon me. It is more an upsurge of feeling, literally a rush that comes over and flows through me. With children, the first rush of movement is evident as an unbridled enthusiasm for running, leaping, charging, diving, plunging into a landscape (and waterscape, seascape, firescape, airscape) of action. They cannot help themselves from doing so. That is not to say that the first rush of movement is always so physically manifested. More subtle motions might involve leaning and turning towards the landscape, floating in the sea, being warmed by a fire, and breathing and smiling into a wind. ${ }^{-}$

The power of human movement resides in the landscape of action. That is the child's experience. Yet we as thinking, rational adults tend not to acknowledge this originating power. We constrain our senses of the first rushes of movement temporally, spatially, bodily and relationally. Intention is ascribed to efficacious movement and stress is placed on moving purposefully. The paradox is that we may try to apprehend the first rush of movement through a sensory retreat from the landscape of action by stressing bodily capacities that were already sensorially intermingled with the landscape. The moving body, even the "lived body" or "bodysubject" that experiences itself as co-existing with the world (cf. Merleau-Ponty, 1962), interposes itself between us and the landscape of action and between intention and action. It gets in the way of full world participation, and blocks an appreciation of that participation in the world.

The first rush of movement that the child experiences is the rush of energy that similarly moves adults. Differences lie in the ways we are brought to our senses of movement and the extent to which movement consciousness becomes a consciousness of movement and whether the realization of what 'I can do' lends itself to an expanded movement consciousness. The first rush of movement is then a moment both of departure and return of significance for human movement that Van den Berg (1962) outlined. A shift in favour of the body, sensing itself in its movements, turns movement consciousness towards the intention of the moving person. Yet it is the glance of another that rehabilitates the sense of being immersed in the landscape of action. We shall follow this development of movement consciousness as moments as well as places of achieving human significance.

The body is realized as landscape," states Van den Berg (1962, p. 107), and this is especially so in the first rush of movement. "[I]ts measurements, its ability, its efficiency and vulnerability can only become apparent when the body itself is forgotten, eliminated, passed over in silence for the occupation or for the landscape for whose sake the passing is necessary" (p. 108). But a "second dimension of the body comes into being" (p. 112, original emphasis) under 
the covert eyes of another or in the apprehension I make of my own movements. The body is seen as a polarity of action within a landscape. Moreover, "the whole landscape with which this body contends is centered in this moving, living 'object"' (pp. 112-113). It takes on an intentional appearance as when the child exclaims "That's mine!" or "I did it!"

Ellen Benswanger (1979) outlines such a shift of consciousness in the child:

Activity implies movement, which in turn implies a subject who is intentionally directed to the world. Before a child can move toward an object or perceive something in motion, the object must elicit his [sic] interest and attention. The toddler moves from "here" to "there" because places have come to be meaningful to him. He knows how to reach the next room "in order to" find something there. The direction, speed, and quality of his movements depend on the setting in which they occur as well as the intention that guides them. A given activity and its setting in lived space thus form a unique totality. (p. 117)

This account of the intentional significance of human movement seems phenomenologically respectable and consistent with adult intentionality. However, Benswanger's assumption of a guiding "intention" directing the child to the world tends to override the appeal of the "setting" of the child's movements. Although the "unique totality" of a "given activity and its setting in lived space" may be attributable to such an "intention," in the first rush of movement there is an elicitation of interest that comes from the world. Landscape remains the necessary correlate of movement experience. It is felt as an underlying kinesthetic awareness. Only secondarily, by recourse to external sensations and predominantly to the power sight, can it be claimed that:

Human movement is an active response that transforms and restructures the relation between subject and world. When the young child learns to stand and to walk, he transforms his perspective and encounters a different reality. When he discovers how to pry open the attic door, a new realm becomes accessible for him to explore. Balancing a block tower, removing the contents of the kitchen cupboard, searching for a favorite toy - each activity requires a different intentional stance and a different combination of movements. (ibid.)

Only secondarily, reflectively, and with a developmentalist eye on the child can it be said that:

Through his activities in space, the child learns to coordinate his sensory and motor functions and organize them in a coherent unity. In these early experiences, there is already a continuity of meaning between that which is seen and heard, between touch, vision, and movement. The human body accomplishes a synthesis of its own functions and reflects a system of coordinated senses and movements. (ibid.) 
The significance of human movement is thereby taken personally, individually, bodily, and with optic intentionality. The first rush of movement, with its landscape appeal, is thus taken for the intention of the moving body. Movement is under psycho-motor control.

A third dimension of the body comes into being under the overt gaze of another. The child calls out to the adult standing by: "Come, watch me!" Invariably she fails to perform the movements as well as a moment ago. "Well, I could do it before," she remonstrates. Here, under the gaze of the adult, the child's movements are arrested. They become evidence of a failed intention. But there is also the glance of the adult or of another child that is not so bodily focused and not so disruptive of the child's movement concentration. It is a look that glances off, as if in deflection, the materiality of motion so as neither to alter its course nor diminish its effects. ${ }^{4}$ In fact, Van den Berg (1952) informs us that there is the "look of another...that makes the world bloom and renders the body straighter and suppler...There is a loving look that can bestow a fiat on my work and at the same time justifies the body that does this work" (p. 115). One looks with the child to the activity at hand and in that supportive, loving look, the child is re-embraced by the landscape of action.

It would seem that a bodily apprehension of the landscape of action, on the basis of which it is possible to signify intentional movement, also makes possible a reintegration with the landscape of action. But this return to the landscape is difficult to sustain. Interest, attention and absorption in things that already stand out as the loci of human movement become acts of a willing subject. The intentional movements of this subject, in turn, create a nexus with the world that may, in some situations, constitute a psychological "experience of flow" (Csikszentmihalyi, 1990, 1997, 2000) as a restoration of the landscape of action. But the very construction of "flow" as psychologically exceptional experience, particularly as deep play, peak experience, ultra-flow and so on, makes the restoration and recreation of landscape connections a function of intentional movement rather than being primarily a state of movement receptivity to the appeal, the pull, or the draw of the landscape. It is possible, in other words, to recapture a sense of the first rush of movement; but the human significance of such movement, as residing in the landscape, remains elusive and understated with respect to children for whom this first rush is a primary, enduring consciousness rather than a prior consciousness regained.

\section{The child immersed in movement}

The difficulty in catching a fuller sense of such movement lies in our penchant for identifying and prioritizing the mover, the subject, the adult, and by extension the child, above than the movements per se. This is a penchant, as we have seen, that allows one to locate the significance of human movement in the intention of the moving person rather than in the landscape of action. Motion is furthermore located in this fixity of vision (and super-vision in the case of the child) rather than in the glance or in the landscape itself. Quite simply, we cannot see movement apart from the moving agent, apart from the supposed instigator or the objects that provide its reference points. And with an objectivizing gaze that fixes an otherwise restorative glance we tend to see the moving child against a landscape of action rather than the child moving in ways that are imbued with landscape connections. Such attribution of movement to the human mover, 
although commonsensical, is more like a learned disability than a positive capacity. In this sense, it is manifestly opposed to the ability to see, feel, hear, and, especially, touch the resonances of landscape movements that transcend one-sided intentionality and transform objectifying gazes into glances of movement support. Here we come up against a perceptual myopia, a synaesthetic occlusion that we cannot avoid unless we look more closely at the significance of the children's movements as giving us a primordial and sustaining sense of landscape dwelling.

We turn again to Merleau-Ponty (1964a) who posited a developmental "state of precommunication...wherein the other's intentions somehow play across my body while my intentions play across his" (p. 119, original emphasis). In this first phase of childhood, "there is not one individual over against another but rather an anonymous collectivity, an undifferentiated group life" (ibid.). Subsequently there is differentiation of individuals and distinctions drawn between them that rest on the appropriation of one's own body and one's 'grasp' of the other. "[A] perspective on the other is opened to me from the moment I define him and myself as 'conducts' at work in the world, as ways of 'grasping' the natural and cultural world surrounding us" (p. 117).

More will be said on this "state of pre-communication" in the section to follow. For the moment it is sufficient to indicate a problem in Merleau-Ponty's account that concerns the primary gesture of learning to differentiate between myself and others and the gesture that presumably sets the child on a course of purposive movement. The problem lies with the 'grasp,' which is but one way of handling the world. It has to do with gaining "optimal distance," a "maximum of visibility" and "sharpness of perception" (Merleau-Ponty, 1962, pp. 250, 302), what Herbert Dreyfus (2003) calls "maximum grip." The 'grasp' is but one gesture of apprehending the world, and a very intentional one at that. Accordingly, Merleau-Ponty (1968) rethought his relation to the world and to others and, in some working notes he wrote shortly before he died, he said: "the body stands before the world and the world upright before it, and between them there is a relation that is one of embrace" (p. 271). The range of stances, gestures and expressions of relation to the world need to be considered in addition to the obvious contrast between grasping the things of the world and embracing them. Otherwise we shall not fully 'grasp' the significance of the "state of pre-communication" to which Merleau-Ponty (1964a, p. 119) has drawn our attention. We also will not embrace its sustaining significance in human and other relations.

Let us then shift adult intention, expressed so single-mindedly in the grasping, holding, arresting gestures of visual apprehension that shall ultimately lead to the world's last gasp, to gestures of a different, child-like relationality. Let us consider gestures that arise directly from this pre-communicative state. These are movements, in other words, that resonate with the landscape and express a grace and not merely a grasp. For in grace, gratitude and in the gracious, graceful gesture lies "the manifold nature of the appeal that the world makes, makes in such a way, that the silently transcended body replies to it with a certain attitude or with a certain movement" (Van den Berg, 152, p. 129). ${ }^{\frac{5}{}}$ Let us shift our adult thinking away from the intentional grasp of ingratitude and toward the gestures that, like the expressive glance, are thankful for the movements of a landscape of action and so better identify the child's potential movements. 
Whichever way we turn, however, we seem caught and confined by our adult rationality. A phenomenology that turns the significance of movement around landscape immersion, as has been done so far, needs some help avoiding the reflectively derived adult-oriented attributes of intentional movement. Even allowing for an expanded gestural repertoire of landscape affiliations, the significance of children's movements are easily reducible to adult, operative intentionality. Accordingly, we will introduce a new term, mimesis, and consider now the broadly mimetic cultivation of children's movements. Using environmental examples, we will see that the more-than-intentional significance of children's movements is a function of the mimetic impulse to identify gesturally with the landscape of action. Such identification then gives the precommunicative state of childhood an elevated status as indicative of movement possibilities for children and adults alike.

\section{The mimetic impulse}

Mimesis is a formative impulse of human relationality that finds similarities and forges identifications with others. The present interests in difference, diversity, pluralism, multiculturalism and the many categories of otherness are needed to ward against constructions of individuality, personhood and identity that have waylaid the mimetic impulse. But in the first instance, both phylogenetically and ontogenetically, there is non-differentiation and bodily identification with others, whether that be in the motions of the tribe or in the amniotic space of the womb. The mimetic impulse is "the compulsion to become the Other" (Taussig, 1993, xviii) in "an overall relation of identification" (Bourdieu, 1980, p. 73). It surfaces in love, longing, caring, empathy, sympathy and, indeed, in the cultivation of those ranges of motion that stand with, reach out and look to things that can be held in common. ${ }^{6}$

By the same token, the mimetic impulse is not a totalizing one which would make the Other subject to my intentions.

Mimesis survives as a form of physical resistance to reification and a guarantee of the precedence of the object. Repressed mimesis is articulated as a longing for sensuous intimacy. It prompts a movement toward the world and other people; it seeks similarity and opens up the prospect of a temporary overcoming of separateness; it offers a corrective to identifying thought; it opens itself to the nonidentical and thus leads to a broadening of the subject. (Gebauer and Wulf, 1995, p. 314)

Mimesis is not merely emotional or knowledgeable identification with another because the Other is recognized as that which transcends self-identity and challenges my understanding of her, him, or it. It is not merely bodily imitation and mimicry because it draws upon a somatic consciousness of reaching to an Other that eludes my full grasp.

Mimesis is not merely a receptive but also an active process, the results of which manifest singularly subjective aspects. At the centre of the process stands a 
reference to the Other, who is not to be incorporated, but rather approximated. In this movement there is a moment of passivity, a pause in activity, which is characteristic of the "mimetic impulse". (p. 286)

A pause for thought, a momentary arrest of intention, or better still, catching one's breath, holding back, holding the space, or taking a second look, even a wink, a smile, a nod - these are the subtle motions that recognize a non-reducible Otherness and prompt subsequent reflections on the appropriateness of actions motivated by the mimetic impulse to become the Other.

\section{Gestural mimesis}

Pivotal to an appreciation of mimesis is that it is "the ensnaring of me by the other, the invasion of me by the other. It is that attitude whereby I assume the gestures, the conducts, the favorite words, the ways of doing things of those whom I confront" (Merleau-Ponty, 1964a, p. 145). The example is given of the child who spends much time watching a small bird. There comes, with this bird-watching, a "postural impregnation" that is evident in the child's subsequent imitative motions and sounds. He chirps like the bird, moving his head and body in ways the bird suggests. He moves as if he were the bird. Merleau-Ponty concludes that: "Not only the perception of another child but even that of an animal quite different from the child himself shows up, thanks to the postural function, in attitudes which resemble those of the other and have their same expressive value" (p. 145). An adult, by contrast, is more subdued in his or her mimetic identifications.

It is thus that a raven soaring in the distance is not, for me, a mere visual image; as I follow it with my eyes, I inevitably feel the stretch and flex of its wings with my own muscles, and its sudden swoop toward the nearby trees is a visceral as well as a visual experience for me. The raven's loud, guttural cry, as it swerves overhead, is not circumscribed within a strictly audible field - it echoes through the visible, immediately animating the visible landscape with the reckless style or mood proper to that jet black shape. My various senses, diverging as they do from a single, coherent body, coherently converge, as well, in the perceived thing, just as the separate perspectives of my two eyes converge upon the raven and convene there into a single focus. My senses connect up with each other in the things I perceive, or rather each perceived thing gathers my senses together in a coherent way, and it is this that enables me to experience the thing itself as a center of forces, as another nexus of experience, as an Other. (Abram, 1996, pp. 61-62, original emphases)

Common to adult and child is "synaesthetic experience," the intercommunication or co-mingling of the senses (Merleau-Ponty, 1962, p. 229). It is not only about the imbrication of perceptual modalities, or the overlapping of touch, vision, hearing and smell. Instead, it is also implicates 
the kinesthethic sense, and interconnects the enactment of the gestures of mimetic identification with the landscape of action.

The child appears synaesthetically freer, a little more plaint with respect to taking in the landscape. But the adult is nonetheless open to the gestures of landscape identification. ${ }^{7}$ In fact, gestural mimesis provides the means of identifying the meaning of children's movements. Such means are contingent upon a capacity for aligning oneself posturally, positionally and expressively alongside children. A further insight for this phenomenology has to do with the mimetic nature of the motions themselves. Adults can be deeply conscious of children's movement, not just because of adult inclination, disposition and conscious alignment with the trajectories of their motions, but because adults and children are "flesh" of the same carnal world (cf. Merleau-Ponty, 1968). Movement arises mimetically, not merely in the body, but also in the nexus and intertwining of bodily engagement with the world.

Merleau-Ponty (1964a) seems to underrate this mimetic significance of the child's movements when he concerns himself with bodily awareness and the "corporeal or postural schema" that constitute the "consciousness I have of my body" (p. 117). He writes of "the double function of our body." That "[t]hrough its 'sensory fields' and its whole organization [,] the body is, so to speak, predestined to model itself on the natural aspects of the world. But as an active body capable of gestures, of expression, and finally of language, it turns back on the world to signify it" (p. 7). There is a "mimic usage of our body" that does not leave behind corporeal schemata but transposes them to new registers of bodily meaning (ibid.). This "mimetic usage" arises within a "state of pre-communication" or a "syncretic sociability" (p. 120) that we have referred to earlier as the undifferentiated landscape of action. It is the "indistinction between me and the other, a confusion at the core of a situation that is common to us both" (p. 120). This confusion is resolved in the bodily appeal of an intentional movement and in the demarcation of oneself from the landscape through the arresting glances, fixing gazes and defining looks of the other.

Thus at first the [child] $m e$ is both entirely unaware of itself and at the same time all the more demanding for being unaware of its own limits. The adult me, on the contrary, is a me that knows its own limits yet possesses the power to cross them by a genuine sympathy that is at least relatively distinct from the initial form of sympathy. The initial sympathy rests on the ignorance of oneself rather than on the perception of others, while adult sympathy occurs between "other" and "other"; it does not abolish the differences between myself and the other. (p. 120)

But this "state of pre-communication" or "syncretic sociability," that suggests the developmental deficiency of the child's sense of otherness relative to the adult's, carries forward the mimetic impulse and, ironically, is the appeal of so many childhood nostalgias. For example, Edith Cobb (1977) cites Bernard Berenson's recollection of a peak experience, which occurred sometime around six years of age:

As I look back on fully seventy years of awareness and recall the moments of greatest happiness, they were for the most part, moments when I lost myself all 
but completely in some instant of perfect harmony.... In childhood and boyhood this ecstasy overtook me when I was happy out of doors. Was I five or six? Certainly not seven. It was a morning in early summer. A silver haze shimmered and trembled over the lime trees. The air was laden with their fragrance. The temperature was like a caress. I remember -- I need not recall, that I climbed up a tree stump and felt suddenly immersed in Itness. I did not call it by that name. I had no need for words. It and I were one. (p. 32)

To be embraced by the land, the evening, an early summer morning, the thicket of leaves and branches of a lime tree, such are the spaces of rapture, delight and even ecstasy that punctuate a childhood and extend as possibilities of worldly connectedness into adulthood. These are primary mimetic moments of childhood that carry through adulthood. Such moments hold the promise of human connectedness to one another and to the otherness of the world. One might even trace them to the "echolalian" space to which Julia Kristeva refers. The connection of mother, child and world in the amniotic fluidity, "liquid warmth" and "inner surf" of the womb (Ackerman, 1990. p. 78) or to the "oceanic feeling" described by Sigmund Freud where the infant "seems to merge with the beloved or its environment" (Ackerman, 1999, p. 17). Regardless of when the child first connects with the world, "[i]t is important for the adult to have had this childhood period of being in love with the planet, with human existence, and with other humans, for if Merleau-Ponty is right, this is an 'abiding acquisition,' something we gain as a dimension of our being, which as adults we can 'tune into'" (Mazis, 2002, p. 105).

\section{The flesh of childhood}

The insufficiency of a developmentalist account of mimesis in addressing the significance of the children's movement becomes quite apparent when Merleau-Ponty seeks to incorporate the connecting principle of "nature," amongst other principles, within a comprehensive account of human being. He writes:

The notions of Nature and Reason, for instance, far from explaining the metamorphoses which we have observed from perception up to the more complex modes of human exchange, make them incomprehensible. For by relating them to separated principles, these motions mask a constantly experienced moment, the moment when an existence becomes aware of itself, grasps itself, and expresses its own meaning. (Merleau-Ponty, 1964a, pp. 10-11)

A more satisfying account, by which is meant one that pays due heed to the inherent, mimetic significance of children's movement, is indicated by his notion of "the flesh:"

[that] is not matter, is not mind, is not substance. To designate it, we should need the old term "element," in the sense it was used to speak of water, air, earth, and fire, that is, in the sense of a general thing, midway between the spatio-temporal individual and the idea, a sort of incarnate principle that brings a style of being 
wherever there is a fragment of being. The flesh is in this sense an "element" of Being. (Merleau-Ponty, 1968, p. 139)

Drew Leder (1999) extends this notion to "flesh and blood," by pointing out the visceral sensibility that is key to human-world interactions. The reference to "flesh and blood" is the suggestion of a depth to the "flesh" beneath the sensorimotor surface of the body (p. 204). As "flesh and blood" I am in circulation with the world through visceral exchanges with it through inhalation, carbonated exhalation and in the world that enters my blood, "sustaining me from within via its nutritive powers" (p. 205). In movement, "I am not just gazing upon a world, but one who breathes, feeds and drinks of it, such that inner and outer corporeity intertwine" (p. 206). There is, in this circulation, a fluid connectivity and reciprocity. But as an "element of Being," the "flesh" is not only "flesh and blood." It is elemental in its infusion by, and layering of, the elements of "water, earth, air and fire." These elements seep into, support, inspire and warm the flesh of human existence

Merleau-Ponty's idea of the "chiasm" or "criss-crossing" of "the flesh" extends the earlier notion of "synaesthetic experience," reminding us both of our implication in the world and of inevitable separations at times from it (Merleau-Ponty, 1968, pp. 130-155). There is reciprocity, fluidity, and an intermingling of flows in my chiasmic experience of the world, yet there is also divergence and resistance within the chiasm. This divergence and resistance provides the kind of resistance that is necessary for 'grasping' gestures to form. I come to understand through reply and resistance, or better still, through the upsurge of motion and e-motion, that "what we call a visible is...a quality pregnant with a texture, the surface of a depth, a cross section upon a massive being, a grain or corpuscle borne by a wave of Being" (p. 136). I come to understand that we "are of a flesh that moves with this movement of the world" and that instead of always resisting the world's appeal, we can be drawn "into this larger rhythm in order to be alive and add back to the larger mix [our] own distinctive rhythms....This sentient responsiveness only occurs because flesh of all kinds are moving vectors within the world in a kind of circulation among things that is their real body" (Mazis, 2002, p. 2). I come to understand that "[w]e can perceive things at all only because we ourselves are entirely a part of the sensible world that we perceive! We might as well say that we are organs of this world, flesh of its flesh, and that the world is perceiving itself through us" (Abram, 1996, p. 69).

The first rush of movement that one identifies so readily with the child is a "surface of a depth" to the flesh. Offering little resistance to the power of the landscape, the child is situated gesturally amidst the flesh of the world through movements that reciprocate the appeals of the landscapes, the seascapes, the airscapes and firescapes. The child's movements flesh out the mimetic impulse to become the Other. In fact, the power of this impulse is the depth of the flesh that is discerned in the motions of child-like connection to the world. For adults, this first rush of movement is "a pervasive call for return to connection, quietness, wonder, openness, and playful transformation that could lead us to dive back into a remaining pool of childlikeness that is still within us" (Mazis, 2002, p. 111). 


\section{Elemental Gestures}

Merleau-Ponty's "flesh of the world" (1968, pp. 144-146) speaks to our embodied connection and implication in the texture of the world, to which the child's movements attest and which is prior to any self-identifications. It is a variation on the phenomenological formulation of intersubjectivity preceding subjectivity, now cast as a primordial inter-corporeity from which I wrest my individual bodily existence. What needs to be un-learned then, according to MerleauPonty's idea of enfleshment in the world, is how "the primary correlation between material things and bodily experiences undergoes an interpretation in which it is construed as a relationship between physical (extended) and psychological (non-extended) [things]" (Welton, 1999, p. 44). What needs to be re-learned is how the materiality of the world and children's and adults' identifications with it are flesh on flesh, water on water, air on air, earth on earth and fire on fire.

We are implicated in the fleshy fluidity, airiness, earthiness and fieriness of the world whether as material extension or reflection of a prior intercorporeality. On the basis of this implication we can identify with children as they identify with the world within an all-consuming movement and consciousness that arises "at the intersection of tactile sensations and kinaesthetic sensations and, at precisely that juncture where all distance is traversed, undergird[s] the flesh of things with the flesh of the lived-body" (p. 45). There is a felt imperative, which has been called the mimetic impulse, to this fleshy, fluidity, airiness, earthiness and fieriness of the world wherein movement arises not in the body, but in the nexus and intertwining of bodily engagement with the world.

To get a full sense of one's implication in these elements of the world, it is necessary to call upon a "radical reflection." This radical reflection takes note, first of all, of a "reflexive sensing by the lived body" in which the lived body knows itself as the non-object contacting an object-laden world. This radical reflection also takes not of a "reflective and conscious sensing of itself" in which the lived body recognizes itself as sensing itself as perceiving percept, as both the hand being touched and touching hand. Finally, it also takes note of the motions of the lived body which undergird perceptions and show that the "enlived-body, accordingly, is present to itself not only as nexus of sensing but also as locus of movement, even as a system of movements" (pp. 47-48). This radical reflection comes to bear upon the general field of gestural reciprocities and connections. In doing so, it leaves us wondering if really intimate gestures of

the flesh, such as the embrace, the caress and the kiss, are not primordial attunements, motions of rhythm and reciprocity that emanate from the world in identification with it. Such wondering might turn out to be as compelling as the child's first contacts with water, wetness and fluid folds.

With the first vision, the first contact, the first pleasure, there is initiation, that is, not the positing of a content, but the opening of a dimension that can never again be closed, the establishment of a level in terms of which every other experience will henceforth be situated. (Merleau-Ponty, 1968, p. 151)

The eyes and hands and torso and mouth do not just caress, embrace and kiss as gestures of human pleasure - they receive these gestures which emanate from a primordial gesturing in 
space and time, the significance of which is first seen and felt in the rushes of movement that we identify with children. In other words, the viewer is not the center of these gestured experiences, neither in choosing what to give and receive, nor in transforming the perception of giving or receiving into an experience. On the contrary, there is an active elemental force sending the caress. Similarly, the embrace is a folding, enfolding motion which comes from two sides at once; while the kiss, in its fluid connection to another, attunes us to ripples and waves of affect.

\section{Primary motions}

These phenomenological reflections strike a chord in the following narrative taken from Carlos Eire's (2003) remembrances of childhood in pre-Castro Cuba.

Havana by day. Hot, yes, and radiant. The sunlight seemed at once dense and utterly clear. The shadows were so crisp, so cool. The clouds in the blue sky, each one a poem; some haiku, some epic. The sunsets: forget it, no competition. Nothing could compare to the sight of that glowing red disk being swallowed by the turquoise sea and the tangerine light bathing everything, making all of creation glow as if from within. Even the lizards. The waves, those turquoise waves, splashing against the wall of the Malecón, splashing, leaping over it to flood the road, lapping, lapping, lapping endlessly, eternally. Even in the worst of storms the waves were always a lover's caress, an untiring embrace, an endless shower of kisses.

Of course, I didn't think of it that way back then. Get lost. I was a boy. Images of hugs and kisses were unspeakably repulsive. Waves were fun, not sappy drivel. In the worst of storms my brother and I would ask our father, Louis XVI, to drive our car down the Malecón to be swallowed by the breakers. And King Louis was nice enough to comply.

"You know, kids, the saltwater will wreck the car," he would remind us. But he would have as much fun as we did, perhaps more, driving through the surf. And he didn't really care that much about the rust. We loved it, especially when a surging wall of water would nearly tip us over, and the windshield wipers couldn't race fast enough against the deluge. Sometimes we would pack as many of our friends as we could into the car, and my father would bravely take us all to be swallowed by the waves. Car surfing. Without seatbelts, of course. If Havana had been in the United States, the road would have been closed to traffic, and Dad would have been imprisoned for recklessly endangering the lives of children. (pp. 12-13, my emphases)

The experience of the ocean is mediated and quite possibly the adult acts irresponsibly in exposing the children to the elements. But still the recollection captures an elemental sense of 
movement such as was intimated in Margaret Atwood's description of swimming in a lake. ${ }^{7}$ Of particular note in this recollection, and that to which Eire has drawn attention, is the sense of gestural connection to the seascape - of waves that "were always a lover's caress, an untiring embrace, an endless shower of kisses." Of course the child says "Get lost!" to this characterization of his identification with the seascape. Yet like the growing child who claims to be too old for demonstrable shows of parental affection but falls into an embrace, is comforted by a caress and connects with a kiss, there is an enduring significance to these gestures that is lost neither on the child nor on the adult. And so comes the eventual realization that "those clouds, those never-finished, ever-changing poems; and the blazing sunshine, that transfiguring, everlasting kiss; and those waves, those endless caresses - all of them bore witness to the dialogue between a son and his mother" (p. 137).

A realm of gestural associations is hereby opened up, one that has deep ecological value, by this turn to the primary motions of what would normally be considered the affectivities of human relationality. A fully-fleshed-out analysis of the embrace, the caress and the kiss is needed. For the moment, however, it will have to suffice to indicate a promising direction of such an analysis. In this regard, we need glance no further than the landscape and to those deep ecological renditions of landscape connection that highlight these primary motions of connection and identification, not just as metaphors, but as tangible, palpable ways of being in touch withesh of the world. David Abram (1996) writes of the "enveloping earth" (p. 131); Barbara Kingsolver (2002) rails against the "possessive embrace," which is hardly an embrace at all (p. 73), for the sake of "the dark embrace of trees: (p. 85) and the embrace of a world that engages us in its design (p. 191); while Glen Mazis (2002) gives sustained attention to this "embracing earth...[that] holds onto us, giving us the weight to walk, work, and love" (p. 3), and pays heed to the "caresses" of this "sensual and enveloping presence" (p. 66) as well as the "kisses" of "the fields, the wheat, the grapes, the grain, the bees, the sun and the stars" (p. 74). One could go on and on. These writers, like Margaret Atwood and Carlos Eire, draw attention to the elements of human identification and their deep roots in the elements of nature. The earth supports and embraces, water waves beckoningly and caressingly, air and fire kiss and color the flesh of human existence in a more-than-human world.

\section{Cultivated motions}

Elemental gestures are expressed in, though not necessarily captured by, the body disciplines into which the child is drawn and to which the child becomes habituated. Swimming, surfing and diving underwater, along with walking, running, hiking and even dancing, are some of the key body disciplines of water, earth, air and fire. One might say that so, too, are eating, breathing, gardening, composting and the range of ceremonial, meditative and sustaining practices are also built upon these elementary landscape identifications. The sportive disciplines, however, are of particular interest in the movement education of children because they are based upon children's evident movement connections with the world and those movement connections that continue, in the first, second, third, and subsequent rushes of movement to bring a mimetic resonance with the world well into adulthood. 
This insight requires much more than the cursory treatment given here, opening itself to a re-imagination of the sporting disciplines of the body that are currently so contained by brute intentions. It shall have to suffice for a more fully fleshed-out account to indicate the direction for disciplining the elemental gestures of identification. For a start, the very young child who is embraced, caressed and kissed has yet to acquire the bodily schemata of a less adult-shielded identification with the world. By contrast, Margaret Atwood as a child, and even the young Carlos Eire, has acquired the 'means' to swim and surf. The mistake we make, though, is not so much denying the importance of these 'means,' as it is seeing their acquisition and development as a grasp or purchase on the world, rather than as cultivating and disciplining the elementary gestures of landscape identification. Whereas the gaze of intention fixes the glance of attentivenesp of desire perverts the grace, embrace, caress and kiss of mimetic intentionality. But in graceful sporting movements these gestures of movement significance endure, particularly where the movements are of sporting disciplines that appear to connect so readily to the earthscapes, waterscapes, airscapes and firescapes.

Dave Foreman (in Jensen, 2002), founder of "Earth First!" and a leading conservation advocate, says he is happiest in those moments of "not thinking abstractly," when "fully an animal," as say, "in the middle of a rapid on the river having to respond to the river" (p. 6).

I am happiest when I experience the moment entirely for what it is. I'm happiest when I'm bird-watching, or when I'm walking down a trail in the wilderness and the internal dialogue finally ceases - I'm just there in the place. Our physical adaptation is for running or moving through wild country. That's when we're truly human and truly alive. (ibid.)

Foreman speaks to a sustaining "happiness" that is more than fleeting movements of psychological flow. Such happiness is the e-motion of moving in concert with the river, the land, the air and fire through body disciplines that draw from the landscapes of action and return us to them with more finely-tuned appreciations. The motions of childhood that provide an identification with natural landscapes of action are the founding gestures for cultivating these body disciplines. Their mimetic impulsivity is that which subsequently directs the sportive lives of adults away from childish intentions and towards a childlike happiness in moving with the motions of the natural world.

Let us consider three exemplars of bodily disciplines that illustrate what is possible when elementary gestures are so cultivated. Tom Ecott (2001) writes of his encounter with Umberto Pelizzari, the competitive free-diving champion, who tells him: "I don't care why anyone else dives....For me, the sea is life itself. When I go down I am not trying to be a dolphin, or a fish. No, I try to become the water" (p. 319). Ecott goes on to describe Pelizzari in motion:

Umberto Pelizzari has become fluid as water, in water. He is merely a shape, the details of the man masked by the neoprene wetsuit. Now, I am watching an outline of muscle, legs tapering from the cinched waist, long fins flexible as flesh. No detail of skin tone, no strand of hair emerges from the rubber to take the eye away from the simple form of the man. Finally, seeking the air world, he kicks 
with both feet together in unison, fins melded into a dolphin tail, pelvis undulating and thigh muscles straining, torso and stomach flexing, as loose and strong as latex.

Smoothly, and without a splash, Pelizzari's head emerges from the sea, and he reinflates his lungs with a deep breath. The inhalation is vigorous and life-affirming but there is no desperation in his movement. Pelizzari's face is illuminated with pleasure, and he is at peace with his world. I swim back to the boat, enthralled by the grace and beauty of the man, grateful to have shared the sea with him. (p. 326)

Missing from this account, however, is a sense of the residue of childhood motions in Pelizzari's grace in the sea. But it is there nevertheless in Ecott's recollections of growing up in Malaya, swimming and diving in a warm ocean teeming with life. ${ }^{9}$

...when I dive I am eight years old again, everything underwater a fresh object of inquiry. My parents are in their prime and I have everything I want from life without having to do anything about getting it. Perhaps that is where I return to when I breathe underwater. (p. 6)

Phenomenologically speaking, Ecott's description has much in common with biologist Bernd Heinrich's (2001) rendition of ultra-marathon running. For Heinrich, who at forty-one years of age won the North American one hundred kilometre championship, running began as a child in the Black Forest. As he puts it: "I simply love to run. Perhaps that love seeped into my bones back in my childhood, when I ran on that sandy wooded road chasing shiny, metallicgreen tiger beetles. I owe much to that tranquil sylvan existence, where the forest was my playpen" (p. 23). Heinrich takes the lessons he learned in an academic career as an entymologist and biologist as the basis of a training regimen for the marathon, but throughout this mimetically-inspired cultivation of the motions of running, the residue of childhood experience is felt.

When I begin to think about what running is all about for us humans, and why I raced, I was surprised at the vividness of my distant memories, and at my new revelations. There are many worlds between the small boy running barefoot on the sand and the forty-one-year-old biologist wearing Nikes on the Chicago pavement. But now these memories were intertwined in my mind with the larger scheme of human existence that relates to our kinship with animals and goes back to the dawn of humankind. (p. 8)

The third exemplar is Sam Keen (1999) whose dream of flying was first kindled in childhood. It was as a young boy escaping to the woods that, as he puts it, "my spirit soared and I was free" (p. 3). 
Trees, as every boy knows, are for climbing and getting high, and my brother, Lawrence, and I made every effort to break the bonds of earth and live aloft. Even before we saw Tarzan or Kipling's Jungle Book, we knew that we were meant to be airborne. We searched out the trees along the creek that were hung with grapevines and learned to swing from tree to tree, finally falling into a thick mass of what we called pig-vines. When we tired of vines, we climbed to the top of nubile pines and rode the crests to the ground, hoping our weight would not snap the bowed trunks. I spent spellbound hours looking for indigo buntings and lying on my back watching changing cloud pictures. When it was time to go home we checked in and out as quickly as possible, took a supply of peanut-butter sandwiches, and adjourned to our tree houses in the far reaches of the backyard. When the rival neighbourhood gang - the Long Boys - began to threaten our castles in the trees, we spent our scarce dollars for hemp rope that we could climb, pull up, and be secure from attack. Once we found a large warehouse that was filled with cottonseeds, and before we were discovered and thrown out by the watchman, we climbed onto the highest rafters, jumped and fell into the gentle sea of seeds so many times that we began to feel at home in midair. (pp. 3-4)

When Keen subsequently goes to a circus and sees the trapeze artists, his imagination of flying is fired even more. These aerialists seem to be the "extension of everything" that he loves - "trees for climbing, soaring birds" and "freedom from restraint" (p. 5). But the "discipline" needed, what Keen calls the "education of muscle, tendon, and sinew...necessary to teach the spirit to soar" (pp. 6-7), was not taken up until much later, in fact, not until Keen had turned sixty-two years of age. Now, as a practiced trapeze flyer, Keen writes:

On almost any afternoon when I am practicing by myself and the stream [of images from the past and the future] is gurgling, the alchemy happens. The trapeze bar becomes a grapevine and I slip back across a half-century of years into the College Woods and feel the luxurious freedom of an endless summer afternoon stretching before me with nothing to do except hunt for crawfish in the creek or watch a wood thrush feeding her young....It is easy to say, I am just remembering. But, I don't have some black-and-white photographic image of my "inner child" superimposed on the Technicolor experience of the present. I am once again the boy swinging on the vine. (pp. 204-205)

For Keen, as for Pelazzari, Ecott and Heinrich, there is a mimetic impulse to their airscape, waterscape and earthscape motions that connects the times of childhood and adulthood through motions of the flesh. As examplars of movement connection to various landscapes, these individuals show what is possible when body disciplines simply extend a child-like, animated responsiveness to the world; they show an enduring rush of movement. 


\section{Conclusion}

The foregoing study of the essential features of movement consciousness, and of vital movement experiences of childhood, serves as a phenomenological preface to an educational practice called movement education. Such a preface is needed because movement education in its various guises, as physical education, dance education, sport education, outdoor and adventure education, has lost sight of its essential, experiential register. There is general acknowledgement of fun and enjoyment, cathartic exuberance and effort and flow. Movement educators, however, are preoccupied with "the significance of the body carriage" (Redfern, 1965, p. 22) rather than with movement itself as the "essence of life" (Laban, 1948, p. 101). They have lost touch with the "inherent movement impulse [that] needs to be vitalized and guided towards a full and structured expression" (Lisa Ullmann in Laban, 1948, p. 134) by observing only what the body can do, where and how it comports itself, and what it moves in relation to. Movement education pioneers such as Émile Jacques-Dalcroze, Steele Mackay, Genevieve Stebbins, Hede Kallmeyer, Elsa Gindler, Bess Mensendieck, and Rudolf Laban, have been overshadowed by a kind of biomechanics. The same has happened to the dancers, movement educators and physical educators who followed in their footsteps and articulated "vitality affects" (Sheets-Johnstone, 1999, p. 158) such as the elements of movement, the patterns of movement development, and other rushes of motion. This biomechanics confines movement consciousness to realms of purposive, calculative, information processing and reduces the elemental gestures of movement to schemas of psycho-motor skill acquisition.

The phenomenological insights of Maurice Merleau-Ponty, Gabriel Marcel, F.J.J. Buytendijk, J.H. Van den Berg and Richard Zaner amongst others bring a "corporeal turn" (Sheets-Johnstone, 1999) to bear upon the present curricular fields of movement education. They turn attention back to the communicative and expressive significances of the elemental gestures that they help to identify. Primary and cultivated motions attest to landscape connections first felt in the rush of movement. The embrace, caress, and kiss, all commonly expressed human interactions, catch the essential vitality of this first rush. On a scale of adult-child and person-toperson interaction they express experiences of movement that return us to landscapes of fire, air, earth and water. "Flesh" is indeed, as Merleau-Ponty asserted, an "element of being," an "incarnate principle" (Merleau-Ponty, 1968, p. 139), and a mimetic impulse. It is this living, animated body that is fleshed out in a continual return to the first rush of movement. We move in ever more cultivated ways, finding pedagogical direction in sport, dance, gymnastics and movement art disciplines.

A further delineation of what constitutes movement education curricula requires exploring the first rush of movement in relation to other "vitality affects" such as bursts, surges, swells, risings, undulations, waves and flows. "Any time one moves, a vitality affect is present; a certain qualitative dynamic is evident" (p. 257). But here we must not make the mistake of considering movement consciousness merely as an "affect" of movement. The significance of elemental gestures as manifesting the first rush of movement is that movement consciousness is embodied, animating space and time. So, while it will be helpful to explore the range of moods and feelings coloring the affective territory of movement education, of more practical value is a delineation of specific motions that can be cultivated and that comprise a developmental 
movement education. We might, therefore, consider existing curriculum frameworks and reconceptualize their movement categories, constitutive motions and developmental movement patterns to accord with this phenomenology of movement consciousness. Such curriculum considerations have been pursued elsewhere (Lloyd \& Smith, 2005; Smith \& Lloyd, 2006). For the present it must suffice to have provided a necessary prelude to this work.

What the first rush of movement looks like in a variety of activities, how it is sensed, perceived and felt, the specific movement forms it takes, and how such movements are produced, is the stuff of an extended movement education curriculum rooted in experiential knowledge of the body, its animation, and landscape connection. The present study contributes to this curriculum endeavor by addressing, ontologically and phenomenologically, the ground, or landscape connectedness, that comprises movement education. As Maxine Sheets-Johnstone proposes:

If we pursued a study of that common wordless ground, we might find a relationship between our wordless kinetic beginnings and our later wordless celebrations of movement, as at the Olympic Games, a relationship we could readily spell out in terms of the sheer experience of aliveness, the sheer nonverbal kinetic experience of ourselves and others as animate forms. (Sheets-Johnstone, 1999, p. 225)

The phenomenon of the first rush of movement has us realize the degree to which we can feel such vitality, again and again. This is because the first rush of movement is, developmentally and educationally, a recurring rush. Movement education is a lifetime practice of experiencing, with ever greater degrees of movement proficiency, the vital connection to the world and to others that occurs in the first rush of movement.

\section{Endnotes}

${ }^{1}$ Along with Merleau-Ponty (1962), such remembrances "enable us to understand motility as basic intentionality. Consciousness is in the first place not a matter of 'I think that' but of 'I can"' (p. 137).

2 "To be moved' means to come to a different position in regard to one's situation. It is to experience a change in one's Being-toward something or someone or things in general....Actually, emotions are themselves this kind of motion, hence the name 'e-motion" (Mazis, 1993, cited in Cataldi, 1993, p. 45; also see Mazis, 2002, p. 72).

${ }^{3}$ Rushes, along with bursts, surges, swells, risings, undulations, waves and flows are "vitality affects" indicative of not just the quality of movement but the very manner in which one is moving. (See Sheets-Johnstone, 1999, pp. 143-160, 256, 257.) The first rush of movement is distinguished as a primary "vitality affect" rooted, as we shall see, in the elementary motions of landscape identification. 
4 The significance of the glance in maintaining a movement connection to the world is indicated in Edward Casey's (2003) analysis of this initial and formative expression of environmental ethics. Casey's analysis is telling in terms of how the glance reads surfaces, yet goes "under the manifest phenomenon," is fleeting, yet "picks up instantly telltale signs" (p. 188), and, in an "exchange of glances" (ibid.), initiates the "first moment of ethical engagement" with an other (p. 203). But just as the environmental glance is insufficient by itself "to grasp the imperative to remedy the earth's maladies" (p. 198), the child's call to be watched calls for tangible expressions of interest that support and sustain the child's movements and their connections to the landscape of action. In the words of Merleau-Ponty (1964b), which will become understandable in our unfolding analysis of human movement: "Everything depends...upon the fact that our glances are not 'acts of consciousness,' each of which claims an invariable priority, but openings of our flesh which are immediately filled by the universal flesh of the world" (p. 16).

5 There are intimations here of a worldly state of "grace" which, as Charlene Spretnak puts it (in Jensen, 2002), resides in our experiences of "non-duality" and "the perception of the unitive dimensions of being in the cosmos" (p. 44). Whereas such a state of "grace" is often regarded as rare and supernatural, the present analysis seeks to locate it in the ordinarily natural and everyday experiences of children.

${ }^{6}$ Walter Benjamin situates mimesis not as an imitation (or supplement) of nature but as an irreducible, material element of nature itself. "Nature creates similarities," Benjamin contends, citing mimicry as an example. He argues that the human capacity for producing similarities is, however, higher than nature's, since it is rooted in practice and specifically in the practice of becoming-other: "[The human] gift of seeing resemblances is nothing other than a rudiment of the powerful compulsion in former times to become and behave like something else. Benjamin addresses the mimetic faculty in an essay from 1933, "On the Mimetic Faculty" (Benjamin, 1978).

${ }^{7}$ Merleau-Ponty (1962) goes on to tell us that "[s]ynaesthetic perception is the rule, and we are unaware of it only because scientific knowledge shifts the centre of gravity of experience, so that we have unlearned how to see, hear, and generally speaking, feel, in order to deduce, from our bodily organization and the world as the physicist conceives it, what we are to see, hear and feel" (p. 229).

${ }^{8}$ Eire's description is chosen because of the "fun" dimension to it. In this regard it differs from many of the more serious, environmentally and pedagogically correct descriptions of children's encounters with the elements of nature (e.g. Nabhan and Trimble, 1994; Stein, 2001).

9 The formative significance of childhood experiences of the ocean is portrayed vividly in Luc Besson's (1988) film Le Grand Blue that has now become a cult classic amongst free divers. Two Mediterranean childhoods unfold as love affairs with the sea and these childhoods come together in a friendly adult rivalry of diving ever deeper into "the deep blue" ocean. 


\section{References}

Abram, D. (1996). The spell of the sensuous: Perception and language in a more-than-human world. New York: Vintage Books.

Ackerman, D. (1990). A natural history of the senses. New York: Vintage Books.

Ackerman, D. (1999). Deep play. New York: Random House.

Aptekar, L. (1988). Street children of Cali. Durham: Duke University Press.

Atwood, M. (1972). Surfacing. Toronto: McClelland \& Stewart.

Benjamin, W. (1978). On the mimetic faculty. In Reflections: Essays, aphorisms, autobiographical writings . New York: Harcourt Brace Javanovich.

Benswanger, E. G. (1979). A contribution to the phenomenology of lived-space in early childhood. Duquesne studies in phenomenological psychology (volume 3, 111-121). A. Giorgi, R. Knowles and D. L. Smith (eds.). Pittsburgh: Duquesne University Press,

Bourdieu, P. (1980). The logic of practice. Translated by R. Nice. Stanford: Stanford University Press.

Brown, C. S. and Toadvine, T. (2003). (Eds.). Eco-phenomenology: Back to the earth itself. Albany: State University of New York Press.

Buytendijk, F. J. J. (1958). Philosophic basis of human relations. Philosophy Today, 2, 108-112.

Casey, E. S. (2003). Taking a glance at the environment: Preliminary thoughts on a promising topic. In Eco-phenomenology: Back to the earth itself, edited by C. S. Brown and T. Toadvine. Albany: SUNY Press, 187-210.

Cataldi, S.E. (1993). Emotion, depth, and flesh: A study of sensitive space: Reflections on Merleau-Ponty's philosophy of embodiment. Albany: SUNY Press.

Cobb, E. (1977). The ecology of imagination in childhood. New York: Columbia University.

Csikszentmihalyi, M. (1990). Flow: The psychology of optimal experience. New York: Harper and Row. 
Csikszentmihalyi, M. (1997). Finding flow: The psychology of engagement with everyday life. New York: Basic Books.

Csikszentmihalyi, M. (2000). Beyond boredom and anxiety: Experiencing flow in work and play. San Francisco: Jossey-Bass.

Dreyfus, H. L. (2003). A phenomenology of skill acquisition as the basis for Merleau-Pontian non-representationalist cognitive science. Retrieved July $5^{\text {th }}$, 2004 from http://istsocrates.berkeley.edu/ hdreyfus/html/papers.html

Ecott, T. (2001). Neutral buoyancy: Adventures in a liquid world. New York: Grove Press.

Egan, K. (1997). The educated mind. New York: Teachers College Press.

Eire, C. (2003). Waiting for snow in Havana: Confessions of a Cuban boy. New York: The Free Press.

Gardner, H. (1983). Frames of mind: The theory of multiple intelligences. New York: Basic Books.

Grosz, E. (1994). Volatile bodies: Toward a corporeal feminism. Bloomington: Indiana UP.

Gebauer, G. and Wulf, C. (1995). Mimesis: Culture, art, society. Berkeley: University of California Press.

Heinrich, B. (2001). Racing the antelope: What animals can teach us about running and life. New York: HarperCollins.

Jensen, D. (2002). Listening to the land: Conversations about nature, culture, and eros. San Francisco: Sierra Club Books.

Keen, S. (1999). Learning to fly: Trapeze-Reflections on fear, trust and the joy of letting go. New York: Broadway Books.

Kingsolver, B. (2002). Small wonder. New York: Harper Collins.

Laban, R. (1948). Modern educational dance. London: Macdonald and Evans.

Leder, D. (1999). Flesh and blood: A proposed supplement to Merleau-Ponty, The body: Classic and contemporary readings, edited by D. Welton. Malden, MA: Blackwell, 200-210.

Lloyd, R. J. \& Smith, S. J. (2005). A 'vitality' approach to the design, implementation and evaluation of health-related, physical education programs. AVANTE, 11(2), 120- 136. 
MacGregor, R. (2002). Escape: In search of the natural soul of Canada. Toronto: McClelland and Stewart.

Mazis, G. A. (2002). Earthbodies: Rediscovering our planetary senses. Albany: State University of New York Press.

Merleau-Ponty, M. (1962). Phenomenology of perception. London: Routledge and Kegan Paul.

Merleau-Ponty, M. (1964a). The primacy of perception, and other essays on phenomenological psychology, the philosophy of art, history and politics (pp. 96-155), J. M. Edie (ed.). Evanston: Northwestern University Press.

Merleau-Ponty, M. (1964b). Signs. Evanston: Northwestern University Press.

Merleau-Ponty, M. (1968). The visible and the invisible. Evanston: Northwestern University Press.

Nabhan, G. P. and Trimble, S. (1994). The geography of childhood: Why children need wild places. Boston: Beacon Press.

Olkowski, D. \& Weiss, G. (Eds.) (2006). Feminist interpretations of Maurice Merleau-Ponty. University Park, PA: Pennsylvania State University Press.

Redfern, B. (1965). Introducing Laban art of movement. London: Macdonald \& Evans.

Sheets-Johnstone, M. (1999). The primacy of movement. Philadelphia: John Benjamins Publishing Company.

Shusterman, R. (1997). Practicing philosophy: Pragmatism and the philosophical life. New York: Routledge.

Smith, S. J. \& Lloyd, R. J. (2006). Promoting vitality in health and physical education. Qualitative Health Research: An International, Interdisciplinary Journal, vol. 16, no.2, pp. 245-267.

Stein, S. (2001). Noah's children: Restoring the ecology of childhood. New York: North Point Press.

Taussig, M. (1993). Mimesis and alterity: A particular history of the senses. New York: Routledge. 
Van den Berg, J.H. (1952). The human body and the significance of human movement, Philosophy and Phenomenological Research, 13, 159-183.

Welton, D. (1999). "Soft, smooth hands," The Body: Classic and Contemporary Readings, edited by Donn Welton. Oxford: Blackwell, 38-55. 